\title{
Bidirectional effects of moxifloxacin on the pro-inflammatory response in lipopolysaccharide-stimulated mouse peritoneal macrophages
}

\author{
ZHENYU QIU $^{1,2}$, HONGXIA YUAN ${ }^{2}$, NA LI $^{2}$, XINJUAN YANG ${ }^{2}$, XUEMEI HU $^{2}$, FENGTAI SU $^{2}$ and BAIYI CHEN ${ }^{1}$ \\ ${ }^{1}$ Department of Infectious Diseases, The First Hospital of China Medical University, Shenyang, Liaoning 110001; \\ ${ }^{2}$ Department of Infectious Diseases, The First Hospital of Jinzhou Medical University, Jinzhou, Liaoning 121001, P.R. China
}

Received February 1, 2018; Accepted September 14, 2018

DOI: $10.3892 / \mathrm{mmr} .2018 .9569$

\begin{abstract}
Sepsis is a systemic inflammatory condition in response to life-threatening infections, and macrophages are a key source of inflammatory cytokines. Moxifloxacin (MXF) has antibacterial activity in Gram-positive and Gram-negative bacteria. The present study investigated the effects of MXF on a lipopolysaccharide (LPS)-stimulated inflammatory response and gene expression in macrophages. Peritoneal macrophages were isolated from male $\mathrm{C} 57 \mathrm{BL} / 6 \mathrm{~J}$ mice and treated with LPS and/or MXF. The mRNA and protein expression of toll-like receptor 4 (TLR4), sphingosine kinase 1 (SPHK1) and nuclear factor $(\mathrm{NF})-\kappa \mathrm{B}$ was determined by quantitative polymerase chain reaction, western blotting and immunofluorescence analysis. The expression of tumor necrosis factor (TNF)- $\alpha$ and interleukin (IL)- 6 was determined with ELISAs. The data demonstrated that MXF dose-dependently decreased the viability of macrophages, and 8 and $16 \mu \mathrm{g} / \mathrm{ml}$ MXF prevented the LPS-induced increase in TLR4, SPHK1, NF- $\mathrm{B}$ p 65 , TNF- $\alpha$ and IL- 6 expression. The inhibition was most effective at a concentration of $16 \mu \mathrm{g} / \mathrm{ml} \mathrm{MXF}$, whereas, $64 \mu \mathrm{g} / \mathrm{ml}$ MXF exerted a pro-inflammatory effect. Collectively, the data demonstrated a bidirectional effect of MXF: Lower MXF concentrations (8 and $16 \mu \mathrm{g} / \mathrm{ml}$ ) inhibited the inflammatory response; however, a higher MXF concentration $(64 \mu \mathrm{g} / \mathrm{ml})$ had a pro-inflammatory effect on LPS-treated mouse peritoneal macrophages. In conclusion, these results suggested the importance of MXF as an inhibitor of the inflammatory response at an optimal dose. MXF inhibition of the inflammatory response may be mediated by TLR4 signaling.
\end{abstract}

Correspondence to: Dr Baiyi Chen, Department of Infectious Diseases, The First Hospital of China Medical University, 155 Nanjing Northern Street, Shenyang, Liaoning 110001, P.R. China E-mail: chenbaiyi63@163.com

Key words: moxifloxacin, macrophages, lipopolysaccharide, toll-like receptor 4 , sphingosine kinase 1 , infection, cytokine

\section{Introduction}

Sepsis is a leading cause of mortality in hospitals in the USA, which is characterized by a systemic inflammatory response to life-threatening infection and results in widespread tissue injury. Macrophages mediate the innate and adaptive immune response, by producing inflammatory cytokines and cell scavenging $(1,2)$. Macrophages and their monocyte precursors are distributed in every type of tissue in the body. Upon tissue damage or infection, monocytes are rapidly recruited to the lesion site, where they differentiate into tissue macrophages (2-4). Severe sepsis has been demonstrated to induce macrophage dysfunction (2-4). A previous study demonstrated that the endotoxin lipopolysaccharide (LPS) is a ligand of toll-like receptor 4 (TLR4) (5), and the expression of TLR4 is a key determinant of LPS response intensity and susceptibility in a mouse model of infection (6). Furthermore, myeloid differentiation factor 2 (MD-2) is able to bind to TLR4 to form the TLR4/MD-2 complex (7). Following LPS binding to TLR-4/MD-2, toll/interleukin 1 receptor/resistance protein (TIR) domain-containing adaptors are recruited to activate intracellular signaling pathways, including the translocation of nuclear factor $(\mathrm{NF})-\kappa \mathrm{B}$ to the nucleus and production of pro-inflammatory cytokines, including interleukin (IL)-6 and tumor necrosis factor (TNF)- $\alpha$ (8-10). Therefore, TLR4 and its downstream signaling pathways serve a critical role in the regulation of sepsis and sepsis-associated disorders $(11,12)$. As targeting individual inflammatory cytokines in septic states is not a successful strategy, TLR4 is a potential therapeutic target for alleviation of sepsis-induced inflammatory response (13). In addition, sphingosine kinase 1/sphingosine-1-phosphate (SPHK1/S1P) is upregulated in phagocytes and peritoneal phagocytes from patients with severe sepsis (14), suggesting their involvement in sepsis development. LPS may activate the SPHK1/S1P signaling axis in a number of cell types, including macrophages, to trigger the translocation of SPHK1 to the plasma membrane where it converts its substrate sphingosine to the bioactive sphingolipid S1P (15). SPHK1 is increasingly recognized as an important mediator of the inflammatory response elicited by various inflammatory stimuli, including LPS, TNF- $\alpha$ and IL-1 $\beta$, and involves TLR signaling (16-20). Therefore, further study of the role of these mediators in sepsis 
development and response may aid the development of novel strategies to effectively control sepsis.

Quinolones (QNs) are synthetic, broad-spectrum antimicrobial agents that are clinically used against Gram-positive and Gram-negative bacteria (21). These antimicrobial agents have been demonstrated to modify immune and inflammatory responses in vivo and in vitro (21). In this regard, anti-infection treatment should not only consider the bacterial sensitivity and antibiotic potency; however additionally, the association between the in vivo efficacy and immunoregulatory effects of antibiotics. Moxifloxacin (MXF) is a fluoroquinolone that is effective against Gram-positive and Gram-negative bacteria (22). Its bidirectional effects on the activation and inhibition of the immune response were demonstrated by its effects on the production of a number of cytokines (including TNF- $\alpha$ and IL6) in human and murine leukocytes (23). Similar immunomodulatory effects of fluoroquinolones in inflammatory states and infection have additionally been demonstrated in various previous in vitro studies; for example, clinically relevant concentrations of MXF were demonstrated to inhibit the synthesis of inflammatory mediators, including IL-1, TNF- $\alpha$, IL-6 and IL-8, in human peripheral blood mononuclear cells and endothelial cells following LPS stimulation (24).

However, whether MXF affects the LPS-stimulated macrophage inflammatory reaction and whether the regulatory pathway involves TLR4 and SPHK1 remains to be elucidated. In the present study, an in vitro sepsis inflammatory reaction model was initially established in LPS-stimulated mouse peritoneal macrophages. The effects of MXF on pro-inflammatory factor secretion and the underlying mechanisms were subsequently investigated. To assess the effect of MXF on the inflammatory response in LPS-stimulated macrophages, TLR4, SPHK1 and pro-inflammatory factor expression levels were determined by reverse transcription-quantitative polymerase chain reaction (RT-qPCR), western blotting and ELISAs. The present study demonstrated that the TLR4 and SPHK1 pathways mediated the inhibitory effect of MXF on pro-inflammatory factor expression.

\section{Materials and methods}

Isolation and purification of mouse peritoneal macrophages. The present study was approved by the Institutional Care and Use Committee, Experimental Animal Centre of Jinzhou Medical University (Jinzhou, China). A total of 200 male C57BL/6J mice (6-8 weeks old; 20-25 g weight) were obtained from our animal center and housed in standard Plexiglas cages under a controlled temperature $\left(21-25^{\circ} \mathrm{C}\right)$ and $50 \%$ humidity with food and water available ad libitum under a $12 \mathrm{~h}$ light/dark cycle with lights on at 6:00 a.m. Food supply was restricted 3 days prior to the experiments to achieve a target weight of $85 \%$ their expected weight under conditions of unrestricted food access.

To isolate and purify mouse peritoneal macrophages, the mice were euthanized and $70 \%$ ethanol was subsequently sprayed onto the abdomen. The outer layer of the peritoneum was incised using scissors, and ice-cold RPMI-1640 (cat. no. SH30809.01; HyClone; Thermo Fisher Scientific, Inc., Logan, UT, USA) was subsequently injected into the peritoneal cavity using a $5 \mathrm{ml}$ syringe. Subsequent to gently massaging the peritoneum to dislodge any attached cells into the RPMI-1640 medium, the fluid from the peritoneum was collected into a tube using a $5 \mathrm{ml}$ syringe, kept on ice, and centrifuged at $250 \mathrm{x} \mathrm{g}$ at $4^{\circ} \mathrm{C}$ for $5 \mathrm{~min}$. The supernatant was discarded prior to resuspension of cells in RPMI-1640 supplemented with $10 \%$ fetal bovine serum (FBS; cat. no. FSP500; ExCell Bio, Shanghai, China), $100 \mathrm{U} / \mathrm{ml}$ penicillin and $3.7 \mathrm{~g} / 1 \mathrm{NaHCO}_{3}$, and counted using a hemocytometer. Cells were then added into 6-well tissue culture plates at a density of $1 \times 10^{6}$ cells/well and cultured for $2 \mathrm{~h}$ at $37^{\circ} \mathrm{C}$ to ensure their adherence to the substrate; non-adherent cells were removed by gently washing with warm PBS three times. In total, $90 \%$ pure macrophages were collected for the experiments following a previous study (25).

Macrophage treatment. Macrophages were seeded in 6-well plates at a density of $5 \times 10^{5}$ cells/well or 12 -well plates at a density of $2 \times 10^{5}$ cells/well, cultured overnight and subsequently exposed to different conditions of external stimulations and cultured for $24 \mathrm{~h}$ at $37^{\circ} \mathrm{C}$ in a cell culture incubator with $95 \%$ air and $5 \% \mathrm{CO}_{2}$ : i) Control group (normal peritoneal macrophages without any treatment); ii) LPS group (normal peritoneal macrophages treated with $500 \mathrm{ng} / \mathrm{ml} \mathrm{LPS}$ ); iii) $8 \mathrm{MXF} / \mathrm{LPS}$ group (normal peritoneal macrophages treated with $8 \mu \mathrm{g} / \mathrm{ml}$ MXF and $500 \mathrm{ng} / \mathrm{ml}$ LPS for $2 \mathrm{~h}$ ); iv) 16MXF/LPS group (normal peritoneal macrophages treated with $16 \mu \mathrm{g} / \mathrm{ml} \mathrm{MXF}$ and $500 \mathrm{ng} / \mathrm{ml}$ LPS for $2 \mathrm{~h}$ ); v) 32MXF/LPS group (normal peritoneal macrophages treated with $32 \mu \mathrm{g} / \mathrm{ml} \mathrm{MXF}$ and $500 \mathrm{ng} / \mathrm{ml}$ LPS for $2 \mathrm{~h}$; and vi) 64MXF/LPS group (normal peritoneal macrophages treated with $64 \mu \mathrm{g} / \mathrm{ml} \mathrm{MXF}$ and $500 \mathrm{ng} / \mathrm{ml}$ LPS for $2 \mathrm{~h}$ ). Subsequently, total cellular RNA and protein were extracted from these treated macrophages for RT-qPCR and western blotting, or cells were fixed in $4 \%$ formaldehyde at the room temperature for $20 \mathrm{~min}$ prior to immunostaining.

Cell viability MTT assay. Macrophages were seeded in 96-well culture plates at a density of $5 \times 10^{3}$ cells/well and cultured at $37^{\circ} \mathrm{C}$ for $24 \mathrm{~h}$, prior to the addition of various doses of $\operatorname{MXF}(0,50,100,200,400,800$ and 1,600 $\mu \mathrm{g} / \mathrm{ml})$ for $24 \mathrm{~h}$. MTT solution was added to each well to reach a final concentration of $5 \mathrm{mg} / \mathrm{ml}$. After a $2-\mathrm{h}$ incubation at $37^{\circ} \mathrm{C}$, the culture medium was replaced with $200 \mu \mathrm{l}$ dimethyl sulfoxide to solubilize the formazan crystals produced by MTT. The absorbance was measured at $490 \mathrm{~nm}$ with a spectrophotometer and the percentage of viable cells was calculated. The experiment was set to five replicates and repeated at least three times. The growth inhibition was calculated by the equation: \% cell viability $=(O D c-O D t) /\left(O D c-O_{\text {blank }}\right) \times 100$; where ODt and ODc are the optical densities in treated cultures and control cultures, respectively.

$R T-q P C R$. Total RNA was isolated from the treated macrophages using an RNeasy Mini kit (BioTeke Corporation, Beijing, China) and reverse transcribed into cDNA with the M-MuLV Reverse Transcriptase kit (BioTeke Corporation) and incubated at $42^{\circ} \mathrm{C}$ for $50 \mathrm{~min}$ according to the manufacturer's protocols. qPCR was performed in an Exicycler ${ }^{\mathrm{TM}} 96$ Detection system (Bioneer Corporation, Daejeon, Korea) with $10 \mu \mathrm{l}$ reaction mixture, containing $5 \mu$ S SYBR green Master mix (Applied 
Biosystems; Thermo Fisher Scientific, Inc., Waltham, MA, USA), $0.5 \mu \mathrm{l}(10 \mu \mathrm{M})$ of each forward and reverse primer, and $4 \mu \mathrm{l}$ cDNA template with the FastStart SYBR Green Reagents kit (Sigma-Aldrich; Merck KGaA, Darmstadt, Germany) according to the manufacturer's protocol. The qPCR conditions were $95^{\circ} \mathrm{C}$ for $10 \mathrm{~min}$ and 40 cycles of $95^{\circ} \mathrm{C}$ for $10 \mathrm{sec}, 60^{\circ} \mathrm{C}$ for $20 \mathrm{sec}, 72^{\circ} \mathrm{C}$ for $30 \mathrm{sec}$ and held at $4^{\circ} \mathrm{C}$. The primers were synthesized by Invitrogen (Thermo Fisher Scientific, Inc.) and the sequences were as follows: SPHK1 forward, 5'-ACGAGC AGGTGACTAATGAAGA-3' and reverse, 5'-GTGCCCACT GTGAAACGAA-3'; NF- $\kappa$ B forward, 5'-AGCATTAACCTC CTGGAGACG-3' and reverse, 5'-TTGGGAGCACTGCTT TGGAT-3'; TLR4 forward, 5'-GTAGAGATGAATACCTCC TTAGTGT-3' and reverse, 5'-TTTTACAGCGACCAATAA GTATCAG-3'; $\beta$-actin forward, 5'-CTGTGCCCATCTACG AGGGCTAT-3' and reverse, 5'-TTTGATGTCACGCACGAT TTCC-3'. The relative expression level of $m R N A$ was analyzed using the $2^{-\Delta \Delta \mathrm{Cq}}$ method, where $\Delta \Delta \mathrm{Cq}=\Delta \mathrm{Cq}_{\text {treated }}-\Delta \mathrm{Cq}_{\text {control }}$ according to a previous study (26).

Protein extraction and western blotting. Treated peritoneal macrophages were washed with ice-cold PBS twice, lysed in ice-cold radioimmunoprecipitation assay buffer $(50 \mathrm{mM}$ Tris- $\mathrm{HCl} \mathrm{pH} 7.4,150 \mathrm{mM} \mathrm{NaCl}, 1 \% \mathrm{NP}-40,0.1 \%$ sodium dodecyl sulfate, $0.5 \%$ sodium deoxycholate, $2 \mathrm{mM}$ ethylenediaminetetraacetic acid, $50 \mathrm{mM} \mathrm{NaF}, 10 \mu \mathrm{g} / \mathrm{ml}$ leupeptin, $2 \mathrm{mM}$ $\mathrm{Na}_{3} \mathrm{VO}_{4}, 15 \mu \mathrm{g} / \mathrm{ml}$ aprotinin and $1 \mathrm{mM}$ phenylmethane sulfonyl fluoride) on ice for $30 \mathrm{~min}$, homogenized using a vortex and centrifuged $13,000 \mathrm{xg}$ at $4^{\circ} \mathrm{C}$ for $15 \mathrm{~min}$. The supernatant was transferred into a fresh tube and kept on ice, and the protein concentration was determined with a Bradford assay (Bio-Rad Laboratories, Inc., Hercules, CA, USA). Equal amounts of protein samples (30 $\mu \mathrm{g} / \mathrm{lane})$ were loaded and separated by SDS-PAGE (10\% gels), and electrically transferred onto polyvinylidene fluoride membranes at $30 \mathrm{~V}$ for $1 \mathrm{~h}$. Following a rinse in tap water, the membranes were blocked in $5 \%(\mathrm{w} / \mathrm{v})$ fat-free milk at room temperature for $1 \mathrm{~h}$ and incubated overnight with primary antibodies against TLR4 (19811-1-AP; Proteintech, Rosemont, IL, USA) at a dilution of 1:500, SPHK1 (10670-1-AP; Proteintech) at a dilution of 1:1,000 and $\beta$-actin (CAB340MI22; Cloud-Clone Corp, Atlanta, GA, USA) at a dilution of 1:500, NF- $\kappa$ B (10745-1-AP, Proteintech) at a dilution of 1:500, or PKA (55388-1-AP, Proteintech) at a dilution of 1:500, at $4^{\circ} \mathrm{C}$ overnight. The membranes were subsequently incubated with horseradish peroxidase (HRP)-conjugated goat anti-rabbit immunoglobulin $\mathrm{G}$ secondary antibodies (ZB-2305; OriGene Technologies, Inc., Beijing, China) at a dilution of 1:2,000 at room temperature for $90 \mathrm{~min}$. Following three washes with Tris-based saline-0.1\%Tween 20 (T8220; Beijing Solarbio Science \& Technology Co., Ltd., Beijing, China), the blots were visualized with enhanced chemiluminescence (Thermo Fisher Scientific, Inc.) according to the manufacturer's protocol, and the images were captured using the Kodak Image Station 4000R scanner (Kodak, Rochester, NY, USA). The band intensity of the target proteins was quantified using ImageJ software version 1.5.0 (National Institutes of Health, Bethesda, MD, USA).

Immunofluorescence. Cultured macrophages were fixed in $4 \%$ paraformaldehyde at room temperature for $30 \mathrm{~min}$ and
Table I. Viability of mouse peritoneal macrophages following treatment with MXF for $24 \mathrm{~h}$.

\begin{tabular}{lccc}
\hline MXF,$\mu / \mathrm{ml}$ & Mean & SD & Cell inhibition, \% \\
\hline 0 & 0.535 & 0.032 & - \\
50 & 0.436 & 0.025 & 18.44 \\
100 & 0.420 & 0.013 & 21.50 \\
200 & 0.370 & 0.023 & 30.89 \\
400 & 0.181 & 0.015 & 66.23 \\
800 & 0.121 & 0.005 & 77.45 \\
1,600 & 0.108 & 0.011 & 79.88 \\
\hline
\end{tabular}

Half maximal inhibitory concentration, $294.8 \mu \mathrm{g} / \mathrm{ml}$. MXF, moxifloxacin.

subsequently incubated with $1 \%$ Triton X-100 for 15 min followed by $1 \mathrm{~h}$ of blocking in $5 \%$ goat serum (Beyotime Biotechnology, Shanghai, China) at the room temperature. Subsequently, the macrophages from different treatment groups were incubated with specific primary antibodies, including mouse anti-TLR4 (1:100; 19811-1-AP; Proteintech), anti-SPHK1 (1:1,000; 10670-1-AP; Proteintech) and anti-NF- $\mathrm{B}$ p65 (1:1,000; 10745-1-AP; Proteintech) at $4^{\circ} \mathrm{C}$ overnight. Subsequently, macrophages were incubated with Cy3-conjugated secondary anti-mouse antibody (1:2,000; SA00009-1; Proteintech) at them room temperature for $1 \mathrm{~h}$ and the macrophages were mounted onto glass slides with mounting medium containing DAPI. Images were captured at 400x magnifications using a Nikon epifluorescence microscope (Nikon Eclipse E800; Nikon Corporation, Tokyo, Japan). Analysis was performed for 30-50 cells from each sample using the Image Pro Plus 6.0 (Media Cybernetics, Inc., Rockville, MD, USA) and a total of 150-500 cells per treatment group were statistically analyzed.

ELISA. Macrophages were seeded into 24-well culture plates at a density of $1 \times 10^{5}$ cells/well and subsequently treated as detailed above. The supernatant was collected through centrifugation at $1,000 \mathrm{x} \mathrm{g}$ at $4^{\circ} \mathrm{C}$ for $10 \mathrm{~min}$ to assess the expression levels of IL-6 (at a dilution of 1:4, cat. no. SEA079Mu) and TNF- $\alpha$ (cat. no. SEA133Mu) using these ELISA kits according to the manufacturer's protocols (OriGene Technologies, Inc.).

Statistical analysis. The data were expressed as the mean \pm standard error of three repeated experiments and analyzed using one-way analysis of variance followed by Tukey's post-hoc test. All statistical analyses were performed by using Graphpad Prism 5.0 (GraphPad Software, Inc., La Jolla, CA, USA). P<0.05 was considered to indicate a statistically significant difference.

\section{Results}

Assessment of MXF half maximal inhibitory concentration $\left(I C_{50}\right)$ in mouse macrophages. In the present study, a cell viability MTT assay was initially performed to determine cell viability (cytotoxicity) following macrophage treatment with 
Table II. Viability of mouse peritoneal macrophages following treatment with LPS and MXF for $24 \mathrm{~h}$.

\begin{tabular}{lccc}
\hline Treatment & Mean & SD & Cell inhibition, $\%$ \\
\hline $0 \mathrm{mg} / \mathrm{ml}$ & 0.557 & 0.032 & 0.00 \\
$0 \mathrm{mg} / \mathrm{l} \mathrm{MXF}+500 \mathrm{ng} / \mathrm{ml}$ LPS & 0.549 & 0.018 & 1.44 \\
$50 \mathrm{mg} / \mathrm{l} \mathrm{MXF}+500 \mathrm{ng} / \mathrm{ml} \mathrm{LPS}$ & 0.445 & 0.030 & 20.14 \\
$100 \mathrm{mg} / \mathrm{MXF}+500 \mathrm{ng} / \mathrm{ml} \mathrm{LPS}$ & 0.421 & 0.011 & 24.49 \\
$200 \mathrm{mg} / \mathrm{MXF}+500 \mathrm{ng} / \mathrm{ml} \mathrm{LPS}$ & 0.367 & 0.025 & 34.17 \\
$400 \mathrm{mg} / \mathrm{MXF}+500 \mathrm{ng} / \mathrm{ml}$ LPS & 0.182 & 0.018 & 67.25 \\
$800 \mathrm{mg} / \mathrm{MXF}+500 \mathrm{ng} / \mathrm{ml}$ LPS & 0.119 & 0.004 & 78.55 \\
$1,600 \mathrm{mg} / \mathrm{l} \mathrm{MXF}+500 \mathrm{ng} / \mathrm{ml}$ LPS & 0.114 & 0.015 & 79.61
\end{tabular}

Half maximal inhibitory concentration, $281.82 \mu \mathrm{g} / \mathrm{ml}$. MXF, moxifloxacin; LPS, lipopolysaccharide.

different concentrations of MXF in the presence or absence of $500 \mathrm{ng} / \mathrm{ml}$ LPS for $24 \mathrm{~h}$. Higher MXF doses decreased the cell viability and increased the cell inhibition rate (Table I). The $\mathrm{IC}_{50}$ of MXF was $294.8 \mu \mathrm{g} / \mathrm{ml}$, whereas, $\mathrm{IC}_{50}$ of MXF plus LSP was $281.82 \mu \mathrm{g} / \mathrm{ml}$ (Tables I and II).

Bidirectional effects of MXF on the expression of TLR4,

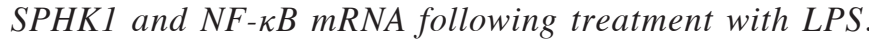
To assess the effects of MXF on the inflammatory response of macrophages, LPS was used to induce the inflammatory response. It was observed that LPS significantly induced the expression of TLR4 $(\mathrm{P}<0.05$; Fig. 1A), SPHK1 $(\mathrm{P}<0.05$; Fig. 1B) and $\mathrm{NF}-\kappa \mathrm{B}(\mathrm{P}<0.05$; Fig. 1C) mRNA, compared with the control group. At doses of 8 and $16 \mu \mathrm{g} / \mathrm{ml}, \mathrm{MXF}$ significantly decreased the expression levels of TLR4, SPHK1 and $\mathrm{NF}-\kappa \mathrm{B}$ mRNA compared with the LPS group $(\mathrm{P}<0.05)$, suggesting that MXF had an inhibitory effect on the inflammatory reaction at lower doses. In contrast, the higher MXF doses (32 and $64 \mu \mathrm{g} / \mathrm{ml}$ ) increased the expression levels of TLR4 $(32 \mu \mathrm{g} / \mathrm{ml}, \mathrm{P}<0.05 ; 64 \mu \mathrm{g} / \mathrm{ml}, \mathrm{P}<0.05)$, SPHK1 $(64 \mu \mathrm{g} / \mathrm{ml}$; $\mathrm{P}<0.05)$ and $\mathrm{NF}-\kappa \mathrm{B}(32 \mu \mathrm{g} / \mathrm{ml}, \mathrm{P}<0.05 ; 64 \mu \mathrm{g} / \mathrm{ml}, \mathrm{P}<0.05)$ mRNA compared with LPS treatment alone, suggesting that high doses of MXF promoted the inflammatory response, although $32 \mu \mathrm{g} / \mathrm{ml}$ MXF had no significant effect on SPHK1 mRNA expression ( $\mathrm{P}>0.05)$.

Bidirectional effects of MXF on the protein expression of

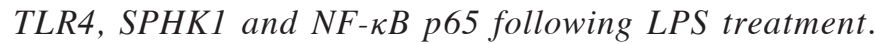
Western blotting (Fig. 2) and immunofluorescence analysis (Fig. 3) was performed to detect alterations in TLR4 (Figs. 2A, 3A and D), SPHK1 (Figs. 2B, 3B and E) and NF- $\mathrm{BB}$ p65 (Figs. 2C, 3C and F) following treatment with LPS. Western blotting demonstrated that the protein expression levels of TLR4, SPHK1 and NF- $\kappa$ B p65 increased following treatment with LPS, compared with the control group $(\mathrm{P}<0.05)$. MXF treatment at 8 and $16 \mu \mathrm{g} / \mathrm{ml}$ downregulated the expression of TLR4 $(\mathrm{P}<0.05)$, SPHK1 $(\mathrm{P}<0.05)$ and NF- $\mathrm{B}$ p65 $(\mathrm{P}<0.05)$, compared with the LPS alone group. These results suggested that low MXF doses prevented the effects of LPS on the expression of these proteins in intestinal macrophages. However, at doses of $32 \mu \mathrm{g} / \mathrm{ml}$, MXF had no significant effect on SPHK1 $(\mathrm{P}>0.05)$ and NF- $\kappa \mathrm{B}$ p65 $(\mathrm{P}>0.05)$ protein expression; however, increased TLR4 expression $(\mathrm{P}<0.05)$ compared with the LPS alone group. At $64 \mu \mathrm{g} / \mathrm{ml}$, MXF increased NF- $\kappa$ B p65 $(\mathrm{P}<0.05)$ expression; however, had no effect on TLR4 $(\mathrm{P}>0.05)$ and SPHK1 $(\mathrm{P}>0.05)$ expression, compared with the LPS alone group. These results suggested that MXF promoted the inflammatory response at higher doses, whereas MXF suppressed the inflammatory response at lower doses.

The immunofluorescence experiments demonstrated that the expression of TLR4, SPHK1 and NF- $\mathrm{B}$ p65 was significantly increased by treatment with LPS compared with the control group $(\mathrm{P}<0.05$; Fig. 3). Treatment with MXF at doses of 8 and $16 \mu \mathrm{g} / \mathrm{ml}$ decreased the expression of TLR4 $(\mathrm{P}<0.05)$, SPHK1 $(\mathrm{P}<0.05)$ and NF- $\kappa \mathrm{B}$ p65 $(\mathrm{P}<0.05)$ compared with the LPS alone group. However, at doses of 32 and $64 \mu \mathrm{g} / \mathrm{ml}$, MXF had no significant effects on the expression of TLR4 $(\mathrm{P}>0.05)$, SPHK1 $(\mathrm{P}>0.05)$ or $\mathrm{NF}-\kappa \mathrm{B}$ p65 $(\mathrm{P}>0.05)$. These results suggested that lower MXF doses inhibited the effects of LPS on the expression of these proteins in intestinal macrophages.

Effects of MXF on IL-6 and TNF- $\alpha$ production following LPS stimulation. After $24 \mathrm{~h}$ of treatment with LPS, the ELISA data demonstrated treatment with LPS resulted in a significant increase of IL-6 and TNF- $\alpha$ expression $(\mathrm{P}<0.05$; Fig. 4) compared with the control group. At doses of 8 and $16 \mu \mathrm{g} / \mathrm{ml}$, MXF decreased the expression of IL-6 (both $\mathrm{P}<0.05$ ) and TNF- $\alpha(\mathrm{P}<0.05$ at $8 \mu \mathrm{g} / \mathrm{ml}$ and $\mathrm{P}<0.05$ at $16 \mu \mathrm{g} / \mathrm{ml})$, compared with the LPS alone group. MXF at $32 \mu \mathrm{g} / \mathrm{ml}$ did not affect the production of IL- 6 and TNF- $\alpha(\mathrm{P}>0.05)$, whereas, MXF at $64 \mu \mathrm{g} / \mathrm{ml}$ significantly increased the expression levels of IL-6 and TNF- $\alpha$ in macrophages, compared with the LPS alone group $(\mathrm{P}<0.05)$. These results supported the effects of MXF on the production of IL- 6 and TNF- $\alpha$ by LPS-stimulated intestinal macrophages.

Effects of MXF on the expression of protein kinase A (PKA) in LPS-stimulated macrophages. As PKA may mediate the effect of MXF on the regulation of synthesis and secretion of these cytokines (27), PKA protein expression in LPS and MXF-treated macrophages was determined (Fig. 5). It was demonstrated that LPS induced PKA expression, whereas low MXF doses prevented the effects of LPS on PKA expression. Higher MXF doses did not exert inhibitory effects, suggesting that the effects of MXF on the synthesis and secretion of the 

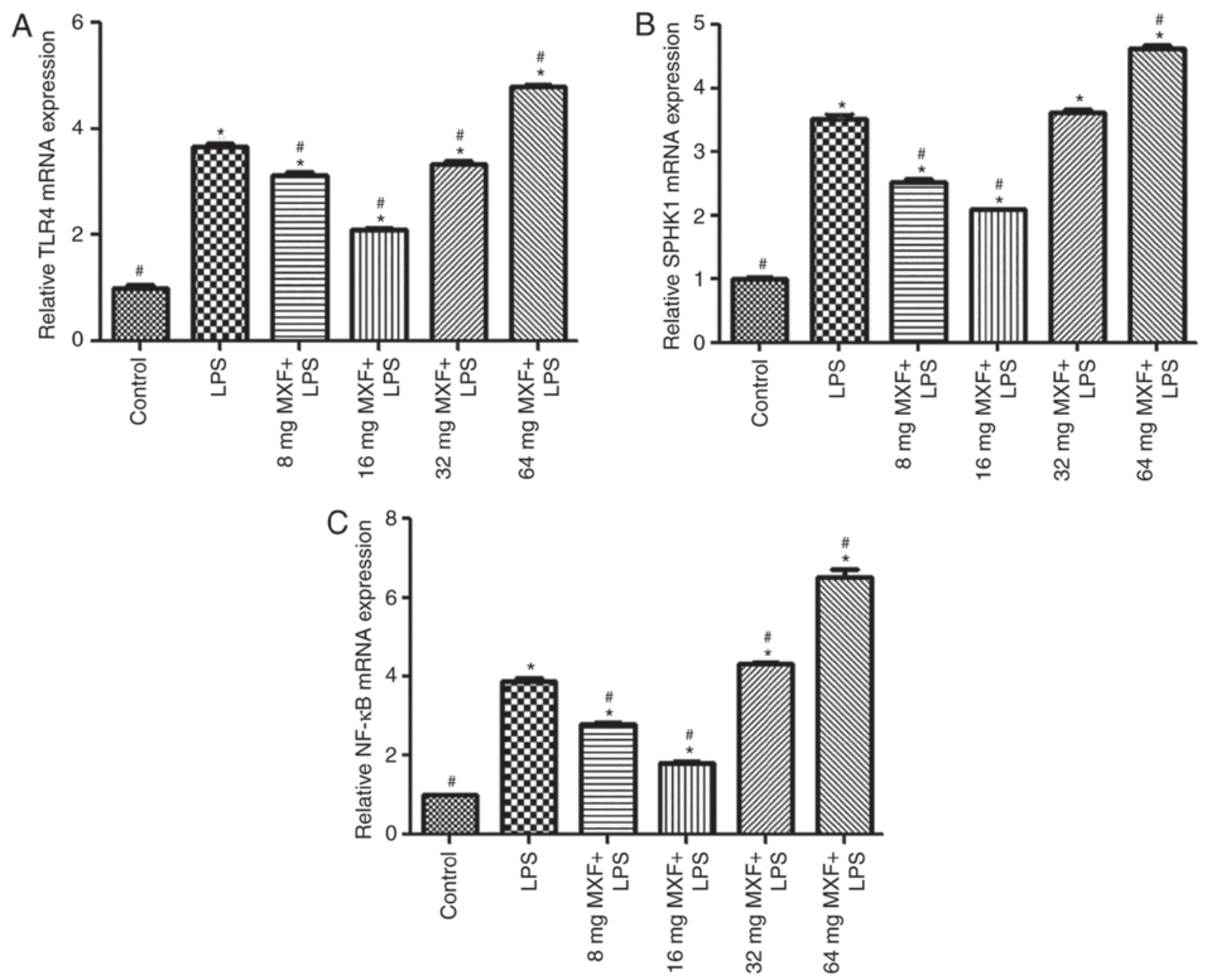

Figure 1. Effects of MXF on the mRNA expression of TLR4, SPHK1 and NF-кB in LPS-stimulated macrophages. Expression levels of (A) TLR4, (B) SPHK1 and (C) NF- $k B$ mRNA were assessed by quantitative polymerase chain reaction assays. The data are expressed as mean \pm standard error of the mean. ${ }^{*} \mathrm{P}<0.05$ vs. the control group; ${ }^{"} \mathrm{P}<0.05$ vs. the LPS group. MXF, moxifloxacin; TLR4, toll-like receptor 4; SPHK1, sphingosine kinase 1; NF- $\mathrm{kB}$, nuclear factor- $\kappa \mathrm{B}$; LPS, lipopolysaccharide.

investigated cytokines may be through PKA suppression in macrophages.

\section{Discussion}

In the present study, it was demonstrated that treatment of macrophages with $16 \mu \mathrm{g} / \mathrm{ml} \mathrm{MXF}$ had the most optimum inhibitory effect on LPS-stimulated expression of NF- $\kappa \mathrm{B}$, TLR4, SPHK1, IL- 6 and TNF- $\alpha$ in mouse peritoneal macrophages. However, this inhibitory effect was attenuated at higher doses of MXF (32 $\mu \mathrm{g} / \mathrm{ml})$ and MXF at $64 \mu \mathrm{g} / \mathrm{ml}$ exerted opposing effects on the expression of these proteins in LPS-treated macrophages. These results suggested that low doses MXF had an inhibitory effect on the inflammatory response, whereas MXF at high doses promoted inflammation. These data were consistent with those reported in a previous study that demonstrated the bidirectional effects of MXF on inflammation (28).

Macrophages are responsible for the clearance of pathogens and additionally instruct other immune cells, and thus have a central role in protecting the host. However, they may additionally contribute to the pathogenesis of inflammatory and degenerative diseases (29). In the present study, mouse peritoneal macrophages were isolated and cultured to further investigate the inflammation-induced molecular mechanisms. The prototypical LPS was used as the endotoxin, due to its ability to bind to the CD14/TLR4/MD-2 receptor complex in macrophages and other cell types, to induce the secretion of pro-inflammatory cytokines, including NF- $\mathrm{KB}$ and transcription factor AP-1 $(30,31)$. Activation of NF- $\mathrm{KB}$ stimulates a number of inflammation-associated transcription factors to subsequently induce the expression of various cytokines, including TNF- $\alpha$ and IL-1/6/8, in addition to adhesins, which may induce the inflammatory response $(32,33)$. Dysregulation of inflammation causes upregulation of cytokines and adhesion expression, which is involved in numerous inflammatory disorders, including endotoxemia and sepsis $(34,35)$. IL-6 and TNF- $\alpha$ are the two most notable pro-inflammatory cytokines secreted by macrophages, and hypersecretion of these cytokines induces widespread tissue damage in the body $(36,37)$. In the present study, LPS was utilized as an agent to induce a pro-inflammatory state. It was demonstrated that the expression of TLR 4 and NF- $\kappa B$, and the secretion of IL- 6 and TNF- $\alpha$ was significantly induced by treatment with LPS, which was consistent with the LPS-induced pro-inflammatory states demonstrated in previous studies $(38,39)$. 
A
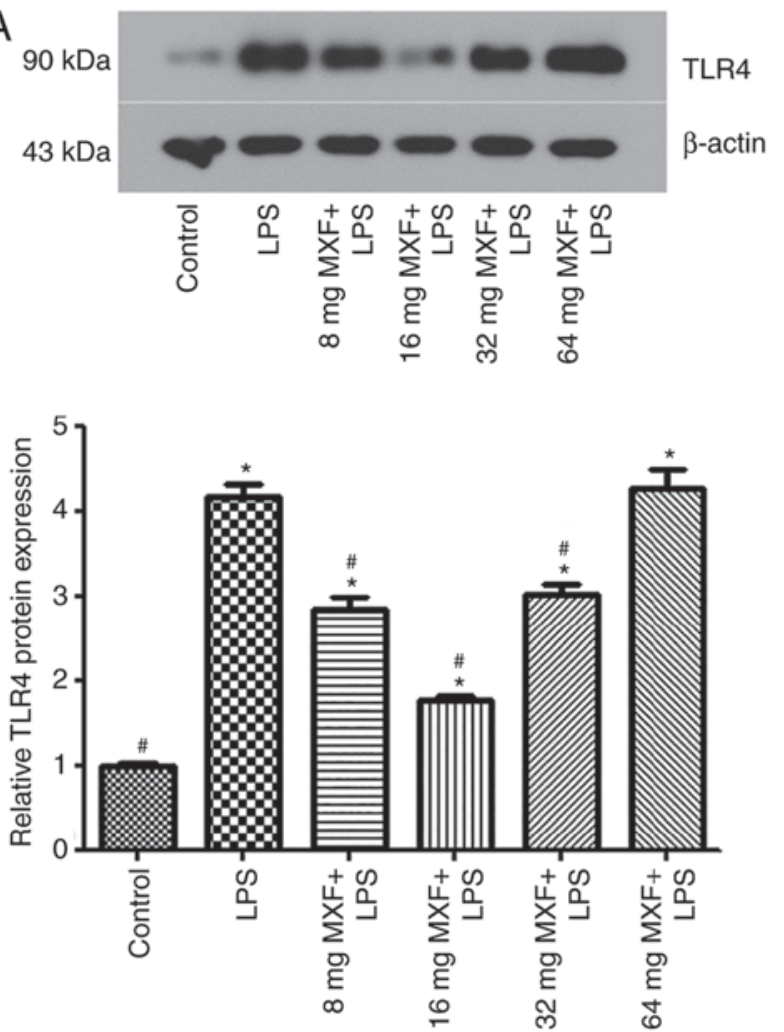

$\mathrm{B}$
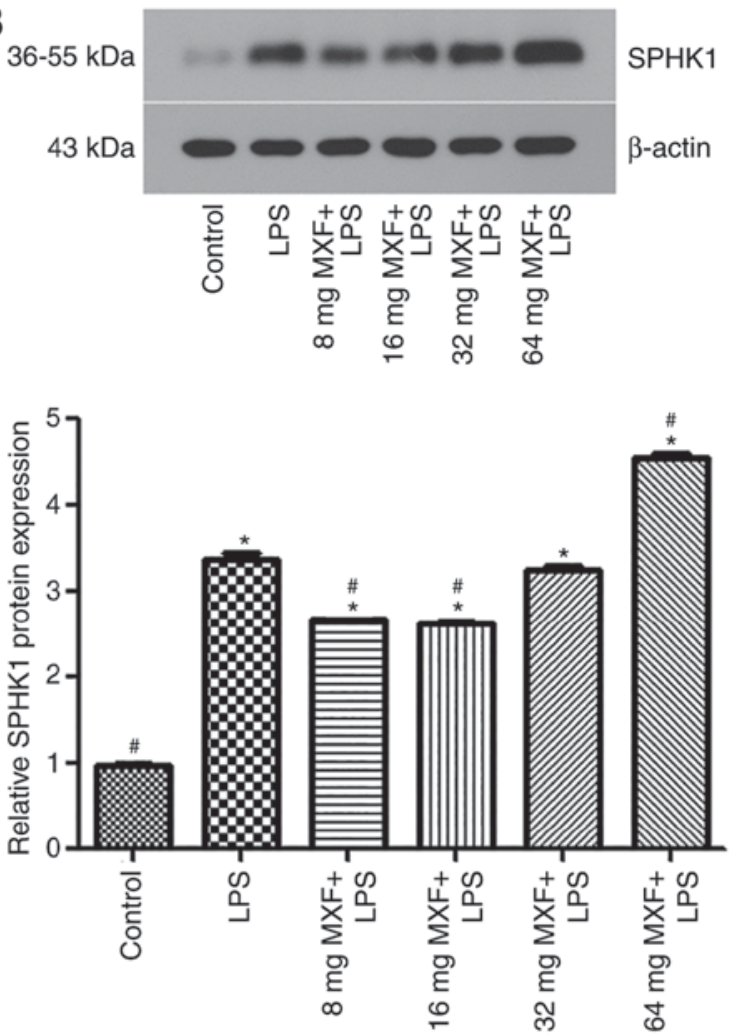
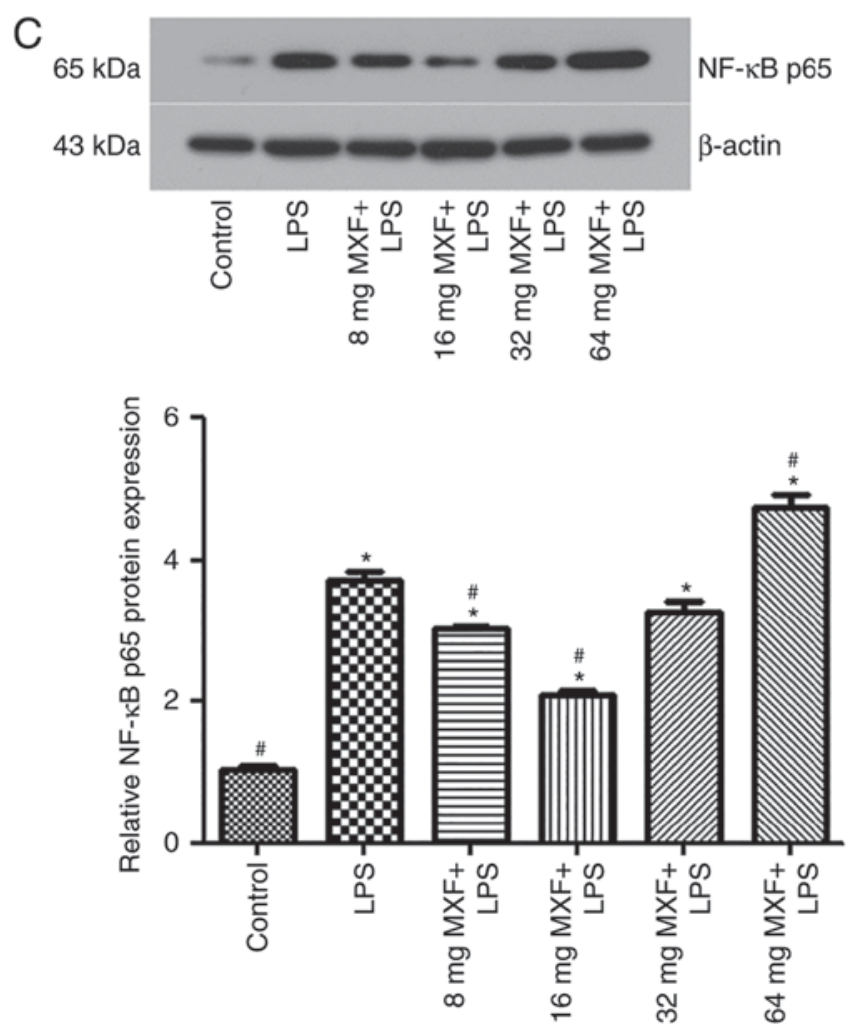

Figure 2. Effects of MXF on the protein expression of TLR4, SPHK1 and NF- $\mathrm{B}$ in LPS-stimulated macrophages by western blotting. Expression levels of (A) TLR4, (B) SPHK1 and (C) NF- $\kappa$ B proteins were measured by western blot analysis. The data are expressed as the mean \pm standard error of the mean. ${ }^{*} \mathrm{P}<0.05$ vs. the control group; ${ }^{*} \mathrm{P}<0.05$ vs. the LPS group. MXF, moxifloxacin; TLR4, toll-like receptor 4; SPHK1, sphingosine kinase 1 ; NF- $\kappa \mathrm{B}$, nuclear factor- $\kappa \mathrm{B}$; LPS, lipopolysaccharide.

Purswani et al (40) demonstrated that MXF was able to regulate the inflammatory reaction in alveolar macrophages and peripheral blood monocytes by decreasing TNF and IL-12 expression, in addition to increasing IL-10 expression. In a previous in vitro study, MXF was demonstrated to prevent the LPS-induced increase in TNF- $\alpha$, IL- 1 and IL- 6 expression in THP-1 cells, cultured from human peripheral blood monocytes (41). The inhibitory effects of MXF on the synthesis 


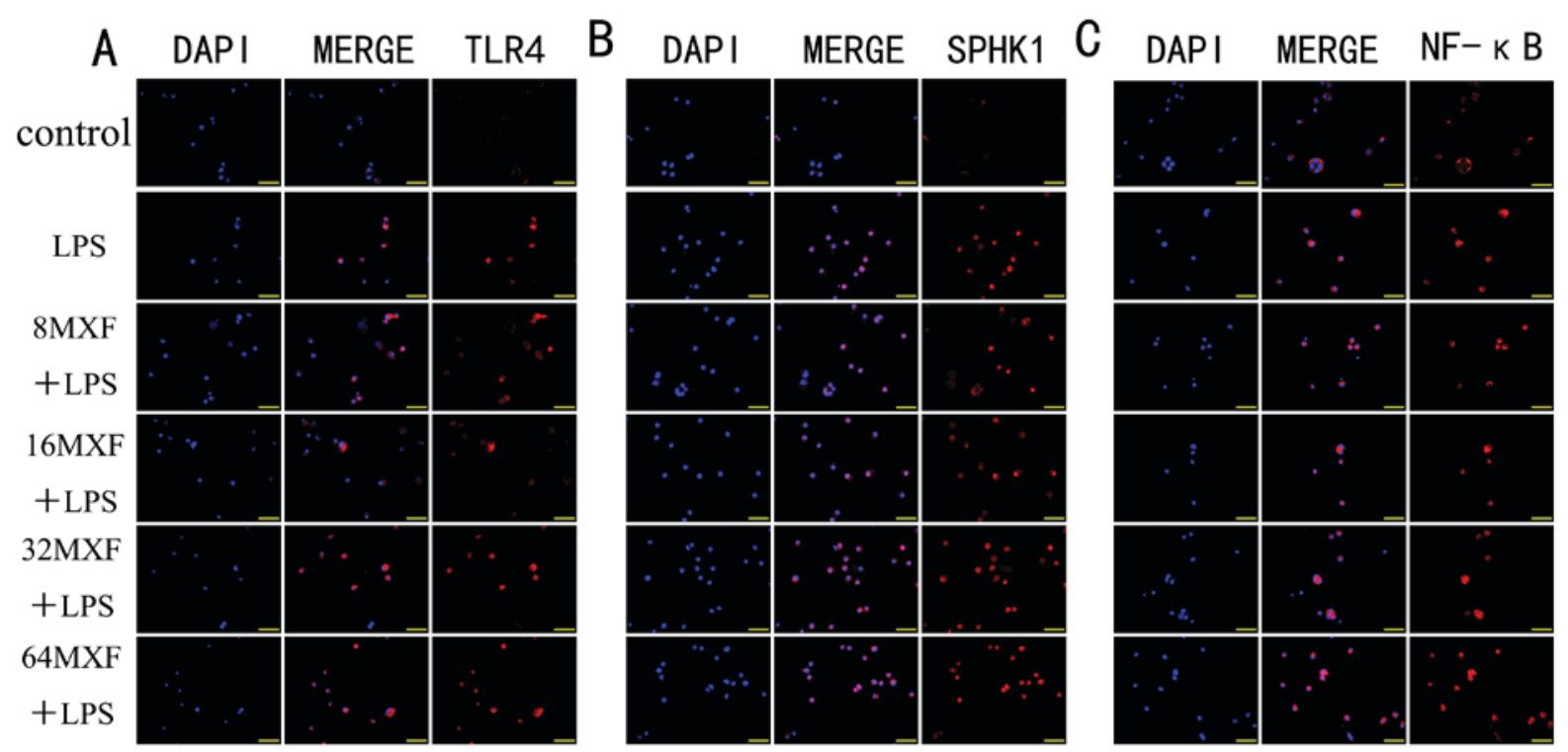

D

E
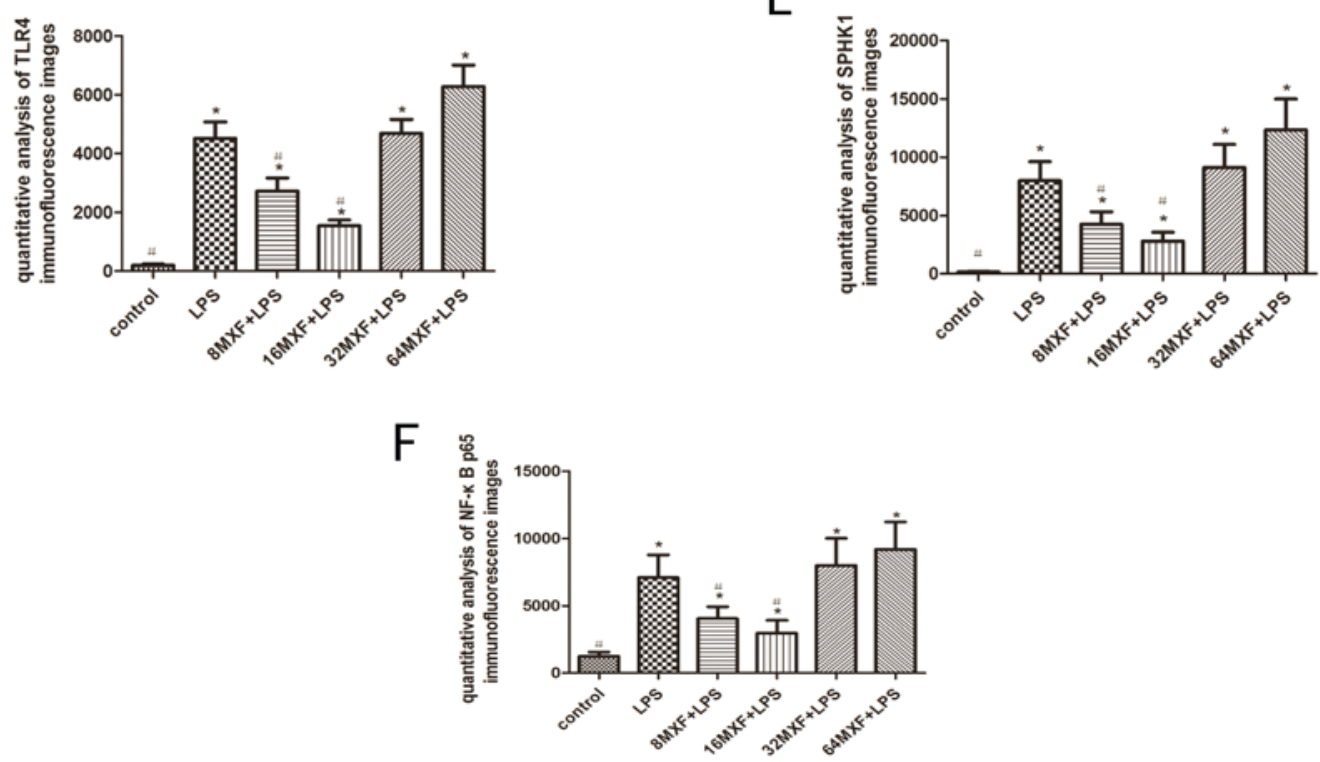

Figure 3. Effects of MXF on the protein expression of TLR4, SPHK1, and NF- $\kappa$ B in LPS-stimulated macrophages by immunofluorescence. Treated macrophages were assessed by immunofluorescence analysis of (A) TLR4, (B) SPHK1 and (C) NF- $\kappa$ B. (D) TLR4, (E) SPHK1 and (F) NF- $\kappa$ B immunofluorescence was quantitatively analyzed. Blue indicates DAPI staining and red indicates (A) TLR4, (B) SPHK1 and (C) NF- $\kappa$. The data are expressed as the mean \pm standard error of the mean. ${ }^{*} \mathrm{P}<0.05$ vs. the control group; ${ }^{*} \mathrm{P}<0.05$ vs. the LPS group. MXF, moxifloxacin; TLR4, toll-like receptor 4 ; SPHK1, sphingosine kinase 1 ; $\mathrm{NF}-\kappa \mathrm{B}$, nuclear factor- $\kappa \mathrm{B}$; LPS, lipopolysaccharide.

and secretion of these cytokines may be associated intracellular signal transduction mechanisms, including the cyclic adenosine monophosphate (cAMP) and PKA pathways (1).

In the present study, MXF doses between 8 and $64 \mu \mathrm{g} / \mathrm{ml}$ were used, which mimicked human clinical doses; MXF is typically administered at $400 \mathrm{mg}$ twice a day in adults, and the half-life of MXF is 11.5-15.6 h after a single oral dose in human volunteers (42-44). One hour after taking MXF, the peak plasma concentration is $\sim 4.1 \mathrm{mg} / 1$ after $1 \mathrm{~h}$, and can reach a plasma concentration of $13.5 \pm 0.42 \mathrm{mg} / \mathrm{l}$ following a single oral dose of $400 \mathrm{mg}$ MXF in a volunteer subject (42-44). The present data demonstrated that the $\mathrm{IC}_{50}$ of MXF was $294.8 \mathrm{mg} / \mathrm{l}$, and the maximum concentration of MXF used was $64 \mathrm{mg} / \mathrm{l}$, which was far below the $\mathrm{IC}_{50}$ of $294.8 \mathrm{mg} / 1$, although it was theoretically a very high dose compared with the clinical dosage. The inhibitory effect of QNs on the synthesis of TNF- $\alpha$ may be mediated via a decrease in cAMP degradation, induced by the inhibition of phosphodiesterase (45). There is a close association between the decreased synthesis of intracellular TNF- $\alpha$ and cAMP, since cAMP is additionally a key second messenger (45). MXF may manipulate the function of topoisomerase II and IV, which influence multiple transcription factors and enzymes to interfere with DNA replication, transcription, repair and recombination during cell proliferation and repair (46). Ceramide and sphingosine are phosphorylated by SPHK1 to produce S1P, which inhibits cell apoptosis and promotes cell proliferation through a number of mechanisms, whereas QNs inhibit cell proliferation via an 

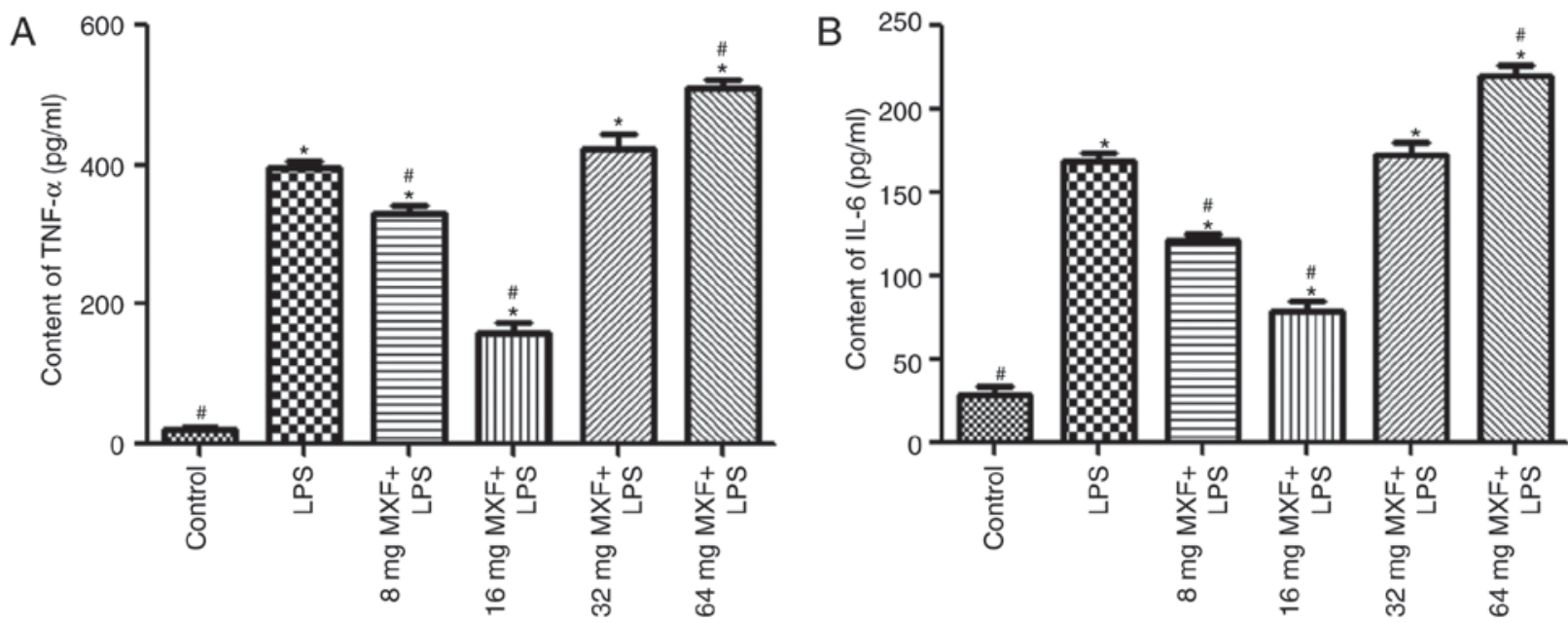

Figure 4. Effects of MXF on IL-6 and TNF- $\alpha$ secretion in LPS-stimulated macrophages. Concentrations of (A) IL- 6 and (B) TNF- $\alpha$ in the culture supernatant were measured by ELISAs. The data are expressed as the mean \pm standard error of the mean. ${ }^{*} \mathrm{P}<0.05$ vs. the control group; ${ }^{*} \mathrm{P}<0.05$ vs. the LPS group. MXF, moxifloxacin; IL, interleukin; TNF- $\alpha$, tumor necrosis factor $\alpha$; LPS, lipopolysaccharide.
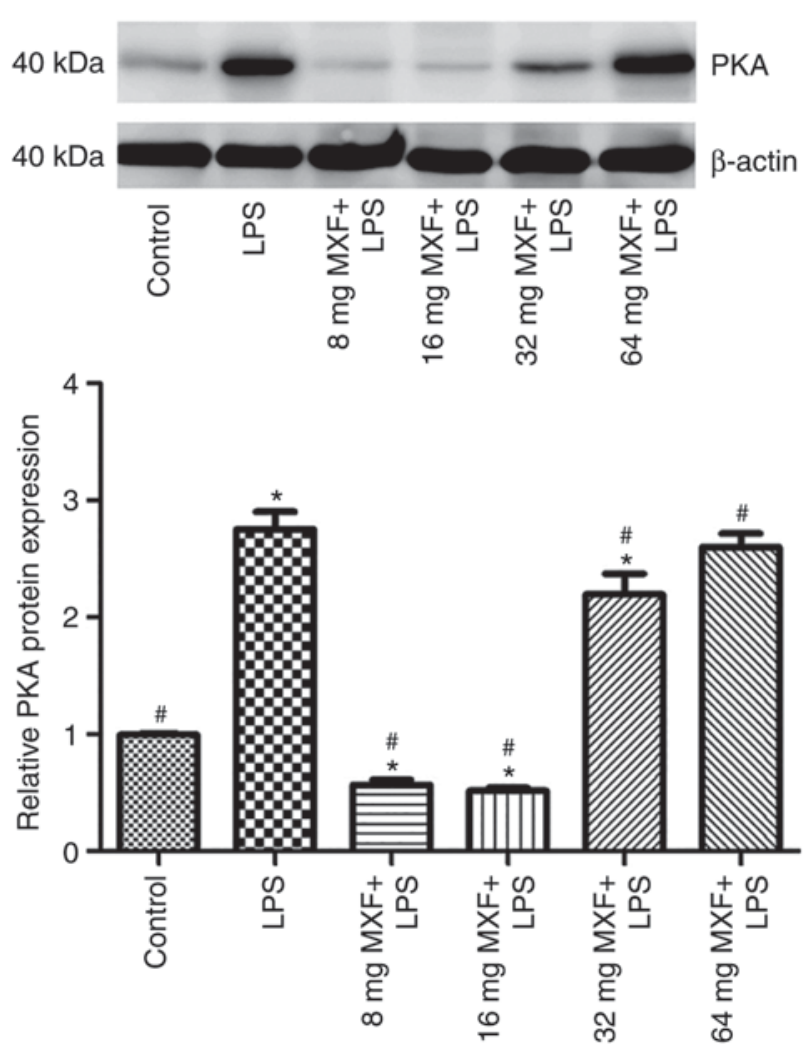

Figure 5. Effects of MXF on the expression of PKA in LPS-stimulated macrophages. Macrophages were treated with $500 \mathrm{ng} / \mathrm{ml}$ LPS in combination with or without different doses of MXF for $2 \mathrm{~h}$ and subsequently subjected to protein extraction and western blotting. Bands were quantified by densitometry. ${ }^{~} \mathrm{P}<0.05$ vs. the control group; ${ }^{~} \mathrm{P}<0.05$ vs. the LPS group. PKA, protein kinase A; LPS, lipopolysaccharide; MXF, moxifloxacin.

opposite mechanism (47,48). Therefore, MXF may inhibit cell proliferation and NF- $\kappa \mathrm{B}$ activity, potentially via inhibition of SPHK1 and topoisomerases. This is a potential mechanism for the observed effects of MXF on inflammation (27).

QNs may affect the transcription factors via direct regulation of cell-membrane receptor activities and various intracellular kinase pathways. However, there is little evidence to suggest that the drug directly binds to the corresponding receptors (including TLR4) or kinases. In the present study, it was demonstrated that low and higher ( 8 vs. $16 \mu \mathrm{g} / \mathrm{ml}$ ) doses of MXF resulted in the same directional alterations in TLR4 and SHPHK1 expression and cytokine secretion in LPS-stimulated macrophages, which suggested that the QNs, receptors and kinases together influence or respond to the inflammation reaction, although the underlying mechanism of the pro-inflammatory effects of MXF at high doses $(64 \mu \mathrm{g} / \mathrm{ml})$ remain to be elucidated. It was hypothesized that this observed phenomenon may be due to the functional integrity impairment of the macrophages.

Moxifloxacin is a fourth-generation QN that has a strong antibacterial activity in Gram-positive and Gram-negative bacteria, and thus has wide clinical uses. In recent years, a number of studies have demonstrated the immunomodulatory effects of MXF (49-52). Anti-infection therapies should not only consider the sensitivity and potency of antibacterial agents; however, the association between antibacterial in vivo efficacy and immunoregulation additionally requires consideration. The application of antibacterial agents is not limited to the treatment of infections; however, may additionally be developed as treatment for diseases of the immune system. Therefore, future studies investigating the immunoregulatory effects of MXF may lead to future clinical applications and further clarification of the underlying mechanisms.

To the best of the authors' knowledge, the present study was the first to investigate the effects of MXF on TLR4 and SPHK1 expression in macrophages, and demonstrated a bidirectional influence of MXF, which may be an important mechanism of the effect of MXF on inflammation. The exact underlying mechanisms of the effect of MXF on TLR4 and SPHK1 expression require further investigation.

\section{Acknowledgements}

Not applicable. 


\section{Funding}

The present study was partially supported by the Liaoning Province Natural Science Foundation of China (grant no. 2015020364).

\section{Availability of data and materials}

The datasets used and/or analyzed during the present study are available from the corresponding author on reasonable request.

\section{Authors' contributions}

ZQ and BC designed the study. ZQ, HY and NL collected and analyzed the data. ZQ, HY, NL, XY, XH and FS contributed samples collection and intellectual input. ZQ drafted and wrote the manuscript. ZQ and $\mathrm{BC}$ revised the manuscript critically for intellectual content. All authors gave intellectual input to the study and approved the final version of the manuscript.

\section{Ethics approval and consent to participate}

The animal study was approved by the Institutional Care and Use Committee, Experimental Animal Centre of Jinzhou Medical University (Jinzhou, China).

\section{Patient consent for publication}

Not applicable.

\section{Competing interests}

The authors declare that they have no competing interests.

\section{References}

1. Underhill DM and Ozinsky A: Phagocytosis of microbes: Complexity in action. Annu Rev Immunol 20: 825-852, 2002.

2. Huang X, Venet F, Wang YL, Lepape A, Yuan Z, Chen Y, Swan R, Kherouf H, Monneret G, Chung CS and Ayala A: PD-1 expression by macrophages plays a pathologic role in altering microbial clearance and the innate inflammatory response to sepsis. Proc Natl Acad Sci USA 106: 6303-6308, 2009.

3. Munoz C, Carlet J, Fitting C, Misset B, Blériot JP and Cavaillon JM: Dysregulation of in vitro cytokine production by monocytes during sepsis. J Clin Invest 88: 1747-1754, 1991.

4. Ayala A and Chaudry IH: Immune dysfunction in murine polymicrobial sepsis: Mediators, macrophages, lymphocytes and apoptosis. Shock 6 (Suppl 1): S27-S38, 1996.

5. Wittebole X, Coyle SM, Kumar A, Goshima M, Lowry SF and Calvano SE: Expression of tumour necrosis factor receptor and Toll-like receptor 2 and 4 on peripheral blood leucocytes of human volunteers after endotoxin challenge: A comparison of flow cytometric light scatter and immunofluorescence gating. Clin Exp Immunol 141: 99-106, 2005.

6. Kalis C, Kanzler B, Lembo A, Poltorak A, Galanos C and Freudenberg MA: Toll-like receptor 4 expression levels determine the degree of LPS-susceptibility in mice. Eur J Immunol 33: 798-805, 2003

7. Fitzgerald KA, Rowe DC and Golenbock DT: Endotoxin recognition and signal transduction by the TLR4/MD2-complex. Microbes Infect 6: 1361-1367, 2004.

8. Medzhitov R, Preston-Hurlburt P and Janeway CA Jr: A human homologue of the drosophila toll protein signals activation of adaptive immunity. Nature 388: 394-397, 1997.
9. Poltorak A, He X, Smirnova I, Liu MY, Van Huffel C, Du X, Birdwell D, Alejos E, Silva M, Galanos C, et al: Defective LPS signaling in $\mathrm{C} 3 \mathrm{H} / \mathrm{HeJ}$ and $\mathrm{C} 57 \mathrm{BL} / 10 \mathrm{ScCr}$ mice: Mutations in Tlr4 gene. Science 282: 2085-2088, 1998.

10. Hoshino K, Takeuchi O, Kawai T, Sanjo H, Ogawa T, Takeda Y, Takeda K and Akira S: Cutting edge: Toll-like receptor 4 (TLR4)-deficient mice are hyporesponsive to lipopolysaccharide: Evidence for TLR4 as the Lps gene product. J Immunol 162: 3749-3752, 1999

11. Xu H, Su Z, Wu J, Yang M, Penninger JM, Martin CM, Kvietys PR and Rui T: The alarmin cytokine, high mobility group box 1, is produced by viable cardiomyocytes and mediates the lipopolysaccharide-induced myocardial dysfunction via a TLR4/phosphatidylinositol 3-kinase gamma pathway. J Immunol 184: 1492-1498, 2010.

12. Brubaker SW, Bonham KS, Zanoni I and Kagan JC: Innate immune pattern recognition: A cell biological perspective. Annu Rev Immunol 33: 257-290, 2015.

13. Feng Y, Gao J, Cui Y,Li M, Li R, Cui C and Cui J: Neuroprotective effects of resatorvid against traumatic brain injury in rat: Involvement of neuronal autophagy and TLR4 signaling pathway. Cell Mol Neurobiol 37: 155-168, 2017.

14. Spiegel S and Milstien S: The outs and the ins of sphingosine-1-phosphate in immunity. Nat Rev Immunol 11: 403-415, 2011.

15. Vyas V, Ashby CR Jr, Olgun NS, Sundaram S, Salami O, Munnangi S, Pekson R, Mahajan P and Reznik SE: Inhibition of sphingosine kinase prevents lipopolysaccharide-induced preterm birth and suppresses proinflammatory responses in a murine model. Am J Pathol 185: 862-869, 2015.

16. Matloubian M, Lo CG, Cinamon G, Lesneski MJ, Xu Y, Brinkmann V, Allende ML, Proia RL and Cyster JG: Lymphocyte egress from thymus and peripheral lymphoid organs is dependent on S1P receptor 1. Nature 427: 355-360, 2004.

17. Tarrasón G, Aulí M, Mustafa S, Dolgachev V, Domènech MT, Prats N, Domínguez M, López R, Aguilar N, Calbet M, et al: The sphingosine-1-phosphate receptor-1 antagonist, W146, causes early and short-lasting peripheral blood lymphopenia in mice. Int Immunopharmacol 11: 1773-1779, 2011

18. Fukuhara S, Simmons S, Kawamura S, Inoue A, Orba Y, Tokudome T, Sunden Y, Arai Y, Moriwaki K, Ishida J, et al: The sphingosine-1-phosphate transporter Spns2 expressed on endothelial cells regulates lymphocyte trafficking in mice. J Clin Invest 122: 1416-1426, 2012.

19. Camaré C, Trayssac M, Garmy-Susini B, Mucher E, Sabbadini R, Salvayre R and Negre-Salvayre A: Oxidized LDL-induced angiogenesis involves sphingosine 1-phosphate: Prevention by anti-S1P antibody. Br J Pharmacol 172: 106-118, 2015.

20. Vettorazzi S, Bode C, Dejager L, Frappart L, Shelest E, Klaßen C, Tasdogan A, Reichardt HM, Libert C, Schneider M, et al: Glucocorticoids limit acute lung inflammation in concert with inflammatory stimuli by induction of SphK1. Nat Commun 6: 7796, 2015.

21. Haruki T, Miyazaki D, Matsuura K, Terasaka Y, Noguchi Y, Inoue Y and Yamagami S: Comparison of toxicities of moxifloxacin, cefuroxime, and levofloxacin to corneal endothelial cells in vitro. J Cataract Refract Surg 40: 1872-1878, 2014.

22. Miravitlles M and Anzueto A: Moxifloxacin: A respiratory fluoroquinolone. Expert Opin Pharmacother 9: 1755-1772, 2008.

23. Shukla P, Verma AK, Dwivedi P, Yadav A, Gupta PK, Rath SK and Mishra PR: Moxifloxacin-loaded nanoemulsions having tocopheryl succinate as the integral component improves pharmacokinetics and enhances survival in E. coli-induced complicated intra-abdominal infection. Mol Pharm 11: 4314-4326, 2014.

24. Blau H, Klein K, Shalit I, Halperin D and Fabian I: Moxifloxacin but not ciprofloxacin or azithromycin selectively inhibits IL-8, IL-6, ERK1/2, JNK, and NF-kappaB activation in a cystic fibrosis epithelial cell line. Am J Physiol Lung Cell Mol Physiol 292: L343-L352, 2007.

25. Lan Q, Yin MZ and Li SP: Separation cultivation and identification of rat peritoneal macrophagee. J Wuhan Univ Technol 31: 40-42, 2009.

26. Livak KJ and Schmittgen TD: Analysis of relative gene expression data using real-time quantitative PCR and the 2(-Delta Delta C(T)) method. Methods 25: 402-408, 2001.

27. Weiss T, Shalit I, Blau H, Werber S, Halperin D, Levitov A and Fabian I: Anti-inflammatory effects of moxifloxacin on activated human monocytic cells: Inhibition of NF-kappaB and mitogen-activated protein kinase activation and of synthesis of proinflammatory cytokines. Antimicrob Agents Chemother 48: 1974-1982, 2004. 
28. Kim A, Lim KS, Lee H, Chung H, Yoon SH, Yu KS, Cho JY, Jang IJ and Chung JY: A thorough QT study to evaluate the QTc prolongation potential of two neuropsychiatric drugs, quetiapine and escitalopram, in healthy volunteers. Int Clin Psychopharmacol 31: 210-217, 2016.

29. O'Neill LA, Kishton RJ and Rathmell J: A guide to immunometabolism for immunologists. Nat Rev Immunol 16: 553-565, 2016

30. Kopp F, Kupsch S and Schromm AB: Lipopolysaccharide-binding protein is bound and internalized by host cells and colocalizes with LPS in the cytoplasm: Implications for a role of LBP in intracellular LPS-signaling. Biochim Biophys Acta 1863: 660-672, 2016.

31. Pahwa R, Devaraj S and Jialal I: The effect of the accessory proteins, soluble CD14 and lipopolysaccharide-binding protein on Toll-like receptor 4 activity in human monocytes and adipocytes. Int J Obes (Lond) 40: 907-911, 2016.

32. Cardenas H, Arango D, Nicholas C, Duarte S, Nuovo GJ, He W, Voss OH, Gonzalez-Mejia ME, Guttridge DC, Grotewold E and Doseff AI: Dietary apigenin exerts immune-regulatory activity in vivo by reducing NF- $\kappa$ B activity, halting leukocyte infiltration and restoring normal metabolic function. Int J Mol Sci 17: 323, 2016

33. Lee AS, Jung YJ, Thanh TN, Lee S, Kim W, Kang KP and Park SK: Paricalcitol attenuates lipopolysaccharide-induced myocardial inflammation by regulating the NF- $\mathrm{NB}$ signaling pathway. Int J Mol Med 37: 1023-1029, 2016.

34. Frieri M, Kumar K and Boutin A: Review: Immunology of sinusitis, trauma, asthma, and sepsis. Allergy Rhinol (Providence) 6: 205-214, 2015.

35. Zhao H, Zheng Q, Hu X, Shen $\mathrm{H}$ and Li F: Betulin attenuates kidney injury in septic rats through inhibiting TLR4/NF- $\mathrm{B}$ signaling pathway. Life Sci 144: 185-193, 2016.

36. Kim YS, Hwang JW, Jang JH, Son S, Seo IB, Jeong JH, Kim EH, Moon SH, Jeon BT and Park PJ: Trapa japonica pericarp extract reduces LPS-induced inflammation in macrophages and acute lung injury in mice. Molecules 21: 392, 2016.

37. Sugiyama K, Muroi M, Kinoshita M, Hamada O, Minai Y, Sugita-Konishi Y, Kamata Y and Tanamoto K: NF- $\kappa$ B activation via MyD88-dependent Toll-like receptor signaling is inhibited by trichothecene mycotoxin deoxynivalenol. J Toxicol Sci 41: 273-279, 2016

38. van der Mark VA, Ghiboub M, Marsman C, Zhao J, van Dijk R, Hiralall JK, Ho-Mok KS, Castricum Z, de Jonge WJ, Oude Elferink RP and Paulusma CC: Phospholipid flippases attenuate LPS-induced TLR4 signaling by mediating endocytic retrieval of Toll-like receptor 4. Cell Mol Life Sci 74: 715-730, 2017.

39. Jurga AM, Rojewska E, Makuch W and Mika J: Lipopolysaccharide from Rhodobacter sphaeroides (TLR4 antagonist) attenuates hypersensitivity and modulates nociceptive factors. Pharm Biol 56: 275-286, 2018.

40. Purswani MU, Eckert SJ, Arora HK and Noel GJ: Effect of ciprofloxacin on lethal and sublethal challenge with endotoxin and on early cytokine responses in a murine in vivo model. J Antimicrob Chemother 50: 51-58, 2002.
41. Shalit I, Halperin D, Haite D, Levitov A, Romano J, Osherov N and Fabian I: Anti-inflammatory effects of moxifloxacin on IL-8, IL-1beta and TNF-alpha secretion and NFkappaB and MAP-kinase activation in human monocytes stimulated with Aspergillus fumigatus. J Antimicrob Chemother 57: 230-235, 2006.

42. Zhang W, Su DH, Zhong HY and Jiang YS: Blood drug concentration and pharmacokinetic analysis of moxifloxacin hydrochloride tablets. Fujian Medical Journal 3: 68-71, 2013.

43. Wise R, Andrews JM, Marshall G and Hartman G: Pharmacokinetics and inflammatory-fluid penetration of moxifloxacin following oral or intravenous administration. Antimicrob Agents Chemother 43: 1508-1510, 1999.

44. Lubasch A, Keller I, Borner K, Koeppe P and Lode H: Comparative pharmacokinetics of ciprofloxacin, gatifloxacin, grepafloxacin, levofloxacin, trovafloxacin, and moxifloxacin after single oral administration in healthy volunteers. Antimicrob Agents Chemother 44: 2600-2603, 2000.

45. Bailly S, Fay M, Roche Y and Gougerot-Pocidalo MA: Effects of quinolones on tumor necrosis factor production by human monocytes. Int J Immunopharmacol 12: 31-36, 1990.

46. Houssaye S, Gutmann L and Varon E: Topoisomerase mutations associated with in vitro selection of resistance to moxifloxacin in Streptococcus pneumoniae. Antimicrob Agents Chemother 46: 2712-2715, 2002

47. Hait NC, Oskeritzian CA, Paugh SW, Milstien S and Spiegel S: Sphingosine kinases, sphingosine 1-phosphate, apoptosis and diseases. Biochim Biophys Acta 1758: 2016-2026, 2006.

48. Xiong H, Wang J, Guan H, Wu J, Xu R, Wang M, Rong X, Huang K, Huang J, Liao Q, et al: SphK1 confers resistance to apoptosis in gastric cancer cells by downregulating Bim via stimulating Akt/FoxO3a signaling. Oncol Rep 32: 1369-1373, 2014.

49. Huckle AW, Fairclough LC and Todd I: Prophylactic antibiotic use in COPD and the potential anti-inflammatory activities of antibiotics. Respir Care 63: 609-619, 2008.

50. Beisswenger C, Honecker A, Kamyschnikow A, Bischoff M, Tschernig T and Bals R: Moxifloxacin modulates inflammation during murine pneumonia. Respir Res 15: 82, 2014.

51. Chen TC and Chang SW: Moxifloxacin modulated TGF- $\beta 1$-related interleukin-12 secretion in corneal fibroblasts. Invest Ophthalmol Vis Sci 58: 5692-5702, 2017.

52. Uehara H, Das SK, Cho YK, Archer B and Ambati BK: Comparison of the anti-angiogenic and anti-inflammatory effects of two antibiotics: Clarithromycin versus moxifloxacin. Curr Eye Res 41: 474-484, 2016.

This work is licensed under a Creative Commons Attribution 4.0 International (CC BY-NC 4.0) License 